DOI: https://doi.org/10.24127/ajpm.v10i4.4417

\title{
ANALISIS KEMAMPUAN KONEKSI MATEMATIS SISWA DITINJAU DARI GAYA BELAJAR
}

\author{
Ully Hidayati ${ }^{1}$, Jahring ${ }^{2}$ \\ ${ }^{1,2}$ Universitas Sembilanbelas November Kolaka, Indonesia \\ *Corresponding author. \\ E-mail: $\quad$ ully_hidayati@usn.ac.id ${ }^{1)}$ \\ jahring.usn@gmail.com $^{2}$
}

Received 10 November 2021; Received in revised form 08 December 2021; Accepted 29 December 2021

\begin{abstract}
Abstrak
Koneksi matematis adalah salah satu kemampuan tingkat tinggi yang harus dimiliki siswa. Namun, setiap siswa memiliki kemampuan koneksi matematis yang berbeda tergantung pada kesesuaian model pembelajaran dengan gaya belajar siswa. Dengan demikian, penelitian ini bertujuan untuk menganalisis dan mendeskripsikan kemampuan koneksi matematis ditinjau dari gaya belajar siswa kelas IX SMP Negeri 1 Tanggetada. Jenis penelitian ini adalah kualitatif yang melibatkan 33 siswa. Instrumen penelitian ini adalah tes kemampuan koneksi matematis dan questioner baku VARK edisi 8.01. Teknik analisis data yang digunakan meliputi reduksi data, penyajian data dan penarikan kesimpulan. Hasil penelitian menunjukkan bahwa: (1) dari 33 siswa terdapat siswa dengan gaya belajar auditory (A) dan read/write (R) masing-masing sebanyak 5 siswa, kinestetic (K) sebanyak 6 siswa, quadmodal yaitu V-A-R-K sebanyak 3 siswa, trimodal yaitu A-R-K dan V-A-K masingmasing sebanyak 2 siswa, bimodal A-K sebanyak 8 siswa dan V-K sebanyak 2 siswa; (2) Kemampuan koneksi matematis siswa kelas IX SMP Negeri 1 Tanggetada berada pada kategori kurang; (3) Rata-rata kemampuan koneksi matematis siswa dengan gaya belajar Auditory (A), Read/write (R) dan Kinestetic (K) berada pada kategori kurang, lalu kemampuan koneksi matematis siswa dengan gaya belajar bimodal tipe A-K dan V-K serta trimodal tipe A-R-K berada pada kategori kurang, kemampuan koneksi matematis siswa dengan gaya belajar trimodal tipe V-A-K berada pada kategori cukup, sedangkan kemampuan koneksi matematis siswa dengan gaya belajar quadmodal V-A-R-K berada pada kategori kurang. Terlihat bahwa kemampuan koneksi matematis siswa kelas IX SMP Negeri 1 Tanggetada berada pada kategori kurang.
\end{abstract}

Kata kunci: Gaya belajar; koneksi matematis.

\begin{abstract}
Mathematical connection is one of the high-level abilities that students must have. However, each student has different mathematical connection abilities depends on the suitability of the learning model with the student's learning style. Thus, this study aims to analyze and describe the ability of mathematical connections in terms of the learning styles of class IX students at SMP Negeri 1 Tanggetada. This type of research is qualitative. The subjects of this study consisted of 33 students. The research instrument is a mathematical connection ability test and a standard questionnaire of VARK 8.01 edition. Data analysis techniques used include (1) data reduction; (data presentation; and (3) drawing conclusions. The results showed that: (1) of the 33 students there were 5 students with auditory learning style (A), 5 students read/write $(R), 6$ students kinesthetic $(K), 3$ students quadmodal, namely VARK, trimodal learning consists of 2 students ARK and 2 students VAK, and bimodal learning style consists of 8 students $A K$ and 2 students VK; (2) The mathematical connection ability of class IX students of SMP Negeri 1 Tanggetada is in the poor category; (3) The average mathematical connection ability of students with Auditory $(A)$, Read/write $(R)$ and Kinesthetic $(K)$ learning styles is in the poor category, students' mathematical connection abilities with bimodal learning styles $A K$ and VK are in the poor category., the mathematical connection ability of students with trimodal learning style ARK type is in the less category and the VAK type is in the sufficient category, and the mathematical connection ability of students with quadmodal learning style, namely VARK is in the less category. It can be seen that the mathematical connection ability of class IX students of SMP Negeri 1 Tanggetada is still in the poor category.
\end{abstract}

Keywords: Learning style; mathematical connection.

This is an open access article under the Creative Commons Attribution 4.0 International License 
DOI: https://doi.org/10.24127/ajpm.v10i4.4417

\section{PENDAHULUAN}

Era revolusi industri 4.0 menyebabkan perubahan dan perkembangan ilmu pengetahuan dan teknologi (IPTEK) disegala bidang kehidupan manusia. Salah satunya adalah di bidang pendidikan. Imbas akan hal tersebut adalah peserta didik dituntut untuk memiliki berbagai kemampuan, seperti berpikir kritis, sistematis, logis, kreatif, bernalar, dan kemampuan bekerja sama yang efektif, (Mandur et al., 2013). Oleh karena itu diperlukan suatu program pendidikan yang dapat menanggulangi hal tersebut. Salah satu program pendidikan yang dapat meningkatkan kemampuan berpikir kritis, sistematis, logis, kreatif, bernalar, dan kemampuan bekerja sama yang efektif adalah matematika.

Matematika adalah suatu cara untuk menemukan jawaban terhadap masalah yang dihadapi manusia, suatu cara menggunakan informasi, menggunakan pengetahuan tentang bentuk dan ukuran, menggunakan pengetahuan tentang menghitung, dan yang paling penting adalah memikirkan dalam diri manusia itu sendiri dalam melihat dan menggunakan hubunganhubungan yang dalam bentuk penyajiannya berupa simbol, bagan, grafik, gambar, kata, dan tabel, yang tidak setiap orang mampu memahami hal tersebut (Haidar \& Jahring, 2020; Hasratuddin, 2013). Menurut (NCTM, 2000) bahwa standar matematika sekolah meliputi standar isi (mathematical content) dan standar proses (mathematical processes), serta meliputi beberapa kemampuan yaitu pemecahan masalah (problem solving), penalaran dan pembuktian (reasoning and proof), keterkaitan (connection), komunikasi (communica-tion), dan representasi (representation).
Koneksi matematis menjadi salah satu kemampuan yang harus dikuasai peserta didik. Secara spesifik, kemampuan koneksi matematis merupakan kemampuan dalam menghubungkan topik dalam matematika, matematika dengan ilmu lain, dan matematika dan kehidupan sehari-hari, yang mana kemampuan ini merupakan salah satu dari berbagai macam kemampuan tingkat tinggi yang harus dimiliki oleh peserta didik, (Jahring, 2020). Jika peserta didik mampu mengaitkan ide-ide matematis, maka pemahaman mereka akan menjadi lebih dalam dan bertahan lama, (Mandur, Sadra, \& Suparta, 2013). Hal ini dikarenakan kemampuan koneksi matematis adalah kemampuan untuk mengaitkan suatu konsep matematika yang satu dengan konsep matematika yang lain, dengan mata pelajaran yang lain, dan dengan aplikasi dalam kehidupan sehari-hari, (Puteri \& Riwayati, 2017). Sehingga ketika peserta didik mampu membuat koneksi dalam matematika, maka peserta didik tersebut mampu untuk memecahkan masalah matematika, melakukan penalaran dan pembuktian terhadap teorema ataupun aksioma matematis, bahkan mampu merepresentasikan matematika kedalam representasi yang mudah dipahami, baik oleh matematikawan, maupun non-matematikawan.

Tidak dapat dipungkiri, kemampuan koneksi matematis setiap peserta didik berbeda-beda, tergantung pada cara mereka menerima materi pelajaran dan modal belajar yang mereka miliki. Berdasarkan hasil wawancara awal dengan guru mata pelajaran Matematika kelas IX SMP Negeri 1 Tanggetada, diketahui sebagian besar siswa kesulitan dalam mengaitkan materi yang dipelajari saat ini dengan materi sebelumnya. Siswa cenderung tidak bisa 
menjawab soal yang berkaitan dengan materi di luar matematika. Selain itu, siswa juga tidak mampu menyelesaikan soal cerita yang berkaitan dengan kehidupan sehari-hari karena mengalami kebingungan untuk menghubungankan soal tersebut dengan konsep dan prosedur matematika.

Hasil wawancara tersebut mengindikasikan kurangnya kemampuan koneksi matematis siswa di kelas IX SMP Negeri 1 Tanggetada. Beberapa penelitian yang telah dilakukan terkait dengan kemampuan koneksi matematis, yaitu (Elisahaya \& Imami, 2020; Isnaeni et al., 2019) yang menganalisis kemampuan koneksi matematis siswa SMP. (Dwiwandira \& Tsurayya, 2021; Manalu et al., 2020) yang mengkaji kemampuan koneksi matematis siswa SMA/SMK. Beberapa penelitian tersebut hanya mengkaji terkait kemampuan koneksi matematis siswa tanpa memperhatikan variabel yang lain sebagai peninjau. Salah satu variabel yang dapat dijadikan peninjau adalah gaya belajar. Menurut (Jahring \& Chairuddin, 2019) bahwa gaya belajar merupakan salah satu aspek penting yang harus diperhatikan, dengan diketahuinya gaya belajar, maka mampu memilih model pembelajaran yang tepat sesuai dengan gaya peserta didik, dan peserta didik mampu menyusun strategi dalam belajar yang sesuai dengan gaya belajarnya. Sehingga mampu meningkatkan kemampuan dan hasil belajarnya. Selain itu, dengan memahami gaya belajarnya, siswa dapat belajar secara aktif sehingga memiliki kemampuan tersendiri dalam memahami konsep dan menyelesaikan masalah matematika, (Mashuri et al., 2020)

Oleh karena itu, tujuan penelitian ini adalah untuk menganalisis dan mendeskripsikan kemampuan koneksi matematis berdasarkan gaya belajar siswa kelas IX SMP negeri 1 Tanggetada. Penelitian ini menjadi sangat penting karena masih minimnya informasi atau referensi tentang gaya belajar siswa, sehingga sebagian besar guru memilih metode pembelajaran dengan tidak mempertimbangkan gaya belajar siswa. Penelitian ini akan memberikan informasi tentang kelompok gaya belajar yang mana yang memiliki kemampuan koneksi matematis paling baik. Sehingga menjadi referensi untuk memberikan treatment khusus bagi kelompok gaya dengan kemampuan koneksi matematis rendah.

\section{METODE PENELITIAN}

Metode penelitian yang digunakan adalah deskriptif kualitatif. Penelitian ini melibatkan seluruh siswa kelas IX SMP Negeri 1 Tanggetada tahun ajaran 2021/2022 sebagai subjek penelitian. Pengambilan sampel sumber data dilakukan secara Proportional Random Sampling. Karena populasinya sebanyak 221 siswa maka dipilih 33 siswa sebagai sampel penelitian. Lalu penentu banyak sampel dilakukan dengan cara mengundi nama siswa pada tiap kelas secara proporsional sehingga diperoleh sampel yang dibutuhkan.

Tahapan dalam penelitian ini meliputi: (1) kunjungan ke sekolah sebagai bentuk observasi terhadap subjek penelitian; (2) menyiapkan instrumen penelitian; (3) melakukan uji coba instrumen penelitian sekaligus menganalisis hasilnya; (4) Pengambilan data terkait kemampuan koneksi matematika dan gaya belajar sekaligus menganalisis hasilnya; (5) menentukan subjek wawancara; (6) melakukan wawancara terhadap subjek penelitian; dan (7) mendeskripsikan kemampuan koneksi matematis siswa dan gaya belajar berdasarkan hasil tes dan wawancara. 
DOI: https://doi.org/10.24127/ajpm.v10i4.4417

Dalam penelitian ini, teknik pengumpulan data yang digunakan yaitu teknik tes (tes kemampuan koneksi matematis), dan teknik non tes (teknik angket dan wawancara). Tes Kemampuan koneksi matematis dalam penelitian ini berupa tes uraian. Adapun indikator kemampuan koneksi matematis dalam penelitian ini yaitu: (1) mampu mengkoneksikan antar topik matematika; (2) mampu mengkoneksikan matematika dengan disiplin ilmu lain; (3) mampu mengkoneksikan matematika dalam dunia nyata atau kehidupan sehari-hari. Instrumen non tes yang digunakan adalah kuisioner VARK yang berisi 16 pertanyaan baku terkait modalitas belajar yang merupakan kuisioner baku yang diadopsi dari The VARK Questionnaire Version 8.1 yang disadur dari www.vark-learn.com.

Teknik analisis data yang dilakukan meliputi: (1) Reduksi Data, yaitu kegiatan yang mengacu pada proses merangkum, memilih hal-hal pokok dan memfokuskan pada hal-hal yang penting agar memberikan gambaran yang lebih jelas; (2) Penyajian Data, dimana dalam penelitian ini, data disajikan dalam bentuk deskriptif dan tabel agar mudah untuk dipahami; dan (3) Penarikan Kesimpulan, yaitu kegiatan konfigurasi yang utuh sehingga mampu menjawab rumusan masalah. Kesimpulan dalam penelitian ini diharapkan mampu memberikan temuan baru berupa deskripsi atau gambaran suatu objek yang sebelumnya masih samar, kemudian diteliti agar lebih jelas. Kesimpulan yang ditemukan akan berupa hasil analisis kemampuan pemahaman konsep matematika siswa ketika ditinjau dari gaya belajar VARK.

\section{HASIL DAN PEMBAHASAN \\ Penggolongan Tipe Gaya Belajar}

Penggolongan gaya belajar siswa kelas IX SMPN 1 Tanggetada diperoleh dari hasil Questionare VARK edisi 8.01. Sebanyak 33 siswa mengisi kuesioner sehingga diperoleh hasil pada Tabel 1.

Tabel 1. Gaya belajar siswa kelas IX SMPN1 Tanggetada

\begin{tabular}{lcc}
\hline $\begin{array}{c}\text { Tipe Gaya } \\
\text { Belajar }\end{array}$ & $\begin{array}{c}\text { Banyak } \\
\text { Siswa }\end{array}$ & Presentase \\
\hline Unimodal & & \\
V & 0 & $0 \%$ \\
A & 5 & $15,15 \%$ \\
R & 5 & $15,15 \%$ \\
K & 6 & $18,18 \%$ \\
Multimodal & & \\
A-K & 8 & $24,24 \%$ \\
V-K & 2 & $6,06 \%$ \\
A-R-K & 2 & $6,06 \%$ \\
V-A-K & 2 & $6,06 \%$ \\
V-A-R-K & 3 & $9,09 \%$ \\
\hline Jumlah & 33 & $100 \%$ \\
\hline
\end{tabular}

Dari Tabel 1 diketahui gaya belajar yang ditemukan pada siswa kelas IX SMPN 1 Tanggetada adalah unimodal dan multimodal. Gaya belajar unimodal adalah gaya belajar dimana siswa hanya memiliki satu tipe gaya belajar, sedangkan gaya belajar multimodal adalah siswa memiliki lebih dari satu tipe gaya belajar. Gaya belajar multimodal terdiri atas tiga bagian yaitu bimodal (kombinasi dua gaya belajar), trimodal (kombinasi tiga gaya belajar), dan quadmodal (kombinasi empat gaya belajar).

\section{Analisis Data Kemampuan Koneksi Matematis Siswa Kelas IX SMPN 1 Tanggetada}

Berdasarkan hasil tes kemampuan koneksi matematis yang diikuti oleh 33 siswa kelas IX SMPN 1 Tanggetada diperoleh data kemampuan koneksi 
DOI: https://doi.org/10.24127/ajpm.v10i4.4417

matematis siswa dalam 4 kategori yaitu baik, cukup, kurang, dan sangat kurang yang disajikan dalam Tabel 2.

Tabel 2. Kemampuan koneksi matematis siswa SMPN 1 Tanggetada

\begin{tabular}{ccc}
\hline $\begin{array}{c}\text { Kemampuan } \\
\text { Koneksi Matematis }\end{array}$ & $\begin{array}{c}\text { Banyak } \\
\text { Siswa }\end{array}$ & Presentase \\
\hline Baik & 7 & $21,21 \%$ \\
Cukup & 8 & $24,24 \%$ \\
Kurang & 10 & $30,30 \%$ \\
Kurang Sekali & 8 & $24,24 \%$ \\
\hline Jumlah & $\mathbf{3 3}$ & $\mathbf{1 0 0 \%}$ \\
\hline
\end{tabular}

Hasil tes kemampuan koneksi matematis pada Tabel 2 memperlihatkan bahwa kemampuan koneksi matematis siswa SMP 1 Tanggetada dengan kategori kurang menduduki posisi teratas. Lalu disusul dengan kategori kurang sekali dan cukup. Sedangkan kategori baik berada pada posisi terbawah. Ini berarti kemampuan koneksi matematis SMP 1 Tanggetada belum memenuhi kondisi yang diharapkan.

Selanjutnya hasil tes akan dikategorikan berdasarkan indikator kemampuan koneksi matematis. Data tersebut dapat dilihat pada Tabel 3.

Tabel 3. Kemampuan koneksi matematis siswa kelas IX SMPN 1 Tanggetada per indikator

\begin{tabular}{lcc}
\hline \multicolumn{1}{c}{$\begin{array}{c}\text { Indikator } \\
\text { Kemampuan } \\
\text { Koneksi Matematis }\end{array}$} & $\begin{array}{c}\text { Rata-rata } \\
\text { tiap } \\
\text { Indikator }\end{array}$ & Kategori \\
\hline $\begin{array}{l}\text { Mampu } \\
\text { mengkoneksikan } \\
\text { antar topik } \\
\text { matematika }\end{array}$ & 63,63 & Kurang \\
$\begin{array}{l}\text { Mampu } \\
\text { mengkoneksikan } \\
\text { matematika dengan } \\
\text { disiplin ilmu lain }\end{array}$ & 49,24 & $\begin{array}{c}\text { Kurang } \\
\text { sekali }\end{array}$ \\
$\begin{array}{l}\text { Mampu } \\
\text { mengkoneksikan } \\
\text { matematika dalam } \\
\text { kehidupan sehari- } \\
\text { hari }\end{array}$ & 65,90 & Cukup \\
\hline \multicolumn{1}{c}{ Rata-rata } & 59,59 & Kurang \\
\hline
\end{tabular}

Tabel 3 menunjukkan bahwa kemampuan koneksi matematis siswa kelas IX SMPN 1 Tanggetada berdasarkan indikatornya berada pada kategori kurang dengan rata-rata 59,59. Adapun rata-rata kemampuan koneksi matematis setiap kelompok gaya belajar disajikan pada Tabel 4.

Tabel 4. Rata-Rata kemampuan koneksi matematis ditinjau gaya belajar siswa kelas IX SMPN 1 Tanggetada

\begin{tabular}{lcc}
\hline $\begin{array}{c}\text { Tipe Gaya } \\
\text { Belajar }\end{array}$ & $\begin{array}{c}\text { Kemampuan } \\
\text { Koneksi } \\
\text { Matematis }\end{array}$ & Kategori \\
\hline Unimodal & & \\
A & 61,67 & Kurang \\
R & 56,67 & Kurang \\
K & 51,39 & Kurang \\
Multimodal & & \\
A-K & 64,52 & Kurang \\
V-K & 58,33 & Kurang \\
A-R-K & 58,33 & Kurang \\
V-A-K & 66,67 & Cukup \\
V-A-R-K & 58,33 & Kurang \\
\hline
\end{tabular}

Tabel 4 menunjukkan bahwa ratarata kemampuan koneksi matematika ditinjau dari tipe gaya belajar secara umum berada pada kategori kurang, hanya pada tipe $\mathrm{V}-\mathrm{A}-\mathrm{K}$ yang mempunyai rata-rata kemampuan koneksi matematis pada kategori cukup.

Untuk mengetahui lebih detail mengenai kemampuan koneksi matematis siswa SMP 1 Tanggetada, maka perlu menganalisa hasil jawaban tes dan wawancara subjek penelitian dari masing-masing tipe gaya belajar berdasarkan indikator kemampuan koneksi matematis.

\section{Kemampuan Koneksi Matematis Ditinjau dari Gaya Belajar Unimodal (U)}

Subjek penelitian yang dipilih untuk gaya belajar Unimodal dengan tipe Auditory (A) adalah U-1, 
DOI: https://doi.org/10.24127/ajpm.v10i4.4417

Read/write (R) adalah U-2, dan Kinestetic (K) adalah U-3. Subjek penelitian tersebut diberikan soal tes kemampuan koneksi matematis dimana soal nomor 1 menyatakan indikator kemampuan mengkoneksikan antar topik matematika, nomor 2 menyatakan indikator kemampuan mengkoneksikan matematika dengan kehidupan seharihari dan soal nomor 3 menyatakan indikator kemampuan mengkoneksikan matematika dengan disiplin ilmu lain.

\section{Subjek U-1}

Subjek U-1 menjawab tiga dari tiga soal yang diberikan. Subjek U-1 mampu menjawab soal nomor 1 dengan tepat dimana Subjek U-1 memahami bahwa konsep mencari luas daerah yang diarsir berkoneksi dengan konsep mencari luas dari bangun datar. Subjek U-1 juga mampu mengkoneksikan konsep matematika dengan kehidupan sehari-hari, yakni dapat menentukan langkah-langkah apa yang akan digunakan yang sesuai dengan permasalahan dalam menyelesaikan soal nomor 2 . Sedangkan untuk soal nomor 3 , subjek U-1 mampu menjawab dengan baik dimana Subjek U-1 juga dapat mengkoneksikan matematika dengan disiplin ilmu lain yakni menghitung berapa waktu yang ditempuh, konsep jari-jari lingkaran dan kecepatan.

\section{Subjek U-2}

Subjek U-2 menjawab tiga dari tiga soal yang diberikan. Subjek U-2 mampu menjawab soal nomor 1 dan 3 yang menyatakan indikator menghubungkan konsep matematika dengan konsep matematika lain dan mampu mengkoneksikan matematika dengan disiplin ilmu lain. Sedangkan pada soal nomor 2, Subjek U-2 tidak memperoleh skor masimal pada indikator mengkoneksikan konsep matematika dengan kehidupan sehari-hari.

\section{Subjek U-3}

Subjek U-3 tidak mampu menjawab soal nomor 1 dan 2 yang masing-masing menyatakan indikator koneksi antar konsep matematika dan koneksi konsep matematika dengan kehidupan sehari-hari. Sedangkan untuk soal nomor 3, Subjek U-3 melakukan kekeliruan dalam perhitungannya sehingga tidak memperoleh skor maksimal yang mewakili indikator mengkoneksikan matematika dengan disiplin ilmu lain.

Berdasarkan hasil analisis tes dan wawancara ditemukan bahwa siswa dengan gaya belajar auditory mampu menguasai semua indikator kemampuan koneksi matematis. Hal ini dikarenakan subjek dengan tipe gaya belajar auditory memiliki kecenderungan mudah memperoleh informasi dengan mendengarkan penjelasan, membaca dengan suara keras. Hasil analisis tipe read/write menunjukkan bahwa siswa belum mampu memenuhi semua indikator kemampuan koneksi matematis, siswa hanya mampu memenuhi 2 indikator yaitu mampu menghubungkan antar topik matematika dan mampu menghubungkan matematika dengan disiplin ilmu lain. Kebiasaan mereka yang sering membaca dan menguatkan dalam bentuk catatan kecil membuat mereka dapat mengingat dan memahami materi sehingga dapat menghubungkan antar topik maupun disiplin ilmu lain dengan matematika. Sedangkan hasil analisis tipe kinestetik menunjukkan bahwa siswa belum memenuhi ketiga indikator kemampuan koneksi matematis. Siswa yang memiliki gaya belajar tipe kinestetik cenderung lebih menyenangi pembelajaran praktik dan pekerjaan nyata. Menurut Jahring \& Chairuddin (2019), siswa dengan tipe gaya belajar 
DOI: https://doi.org/10.24127/ajpm.v10i4.4417

kinestetik, mereka harus merasakan atau menghayati pengalaman belajarnya dan lebih suka simulasi praktek.

\section{Kemampuan Koneksi Matematis Ditinjau dari Gaya Belajar Bimodal (B)}

Subjek Penelitian yang dipilih untuk gaya belajar bimodal dengan tipe Auditory-Kinestetic (AK) adalah B-1 dan Visual-Kinestetic (VK) adalah B-2.

\section{Subjek B-1}

Subjek B-1 mampu menjawab tiga dari tiga soal yang diberikan. Subjek B-1 mampu menjawab soal nomor 1 yang menyatakan indikator mengkoneksikan antar topik matematika. Untuk soal nomor 2 yang menyatakan indikator mengkoneksikan matematika dengan kehidupan seharihari, Subjek B-1 kurang memahami soal yang diberikan sehingga keliru dalam penyelesaiannya. Pada indikator mengkoneksikan matematika dengan disiplin ilmu yang lain yang dinyatakan pada soal nomor 3, subjek B-1 dapat menjawab soal tersebut namun tidak mencapai skor maksimal karena keliru dalam perhitungannya.

\section{Subjek B-2}

Subjek B-2 kurang mampu memahami soal yang diberikan dengan benar. Berdasarkan hasil wawancara, subjek B-2 menyatakan bahwa ia menyelesaikan soal secara asal-asalan tidak sesuai prosedur yang seharusnya. Subjek B-2 juga tidak bisa menjawab ketika ditanya apakah ada hubungan matematika dengan kehidupan seharihari dan disiplin ilmu yang lain dalam soal tersebut.

Hasil analisis tes dan wawancara menunjukkan bahwa siswa dengan tipe belajar Auditory-Kinestetic belum bisa memenuhi semua indikator kemampuan koneksi matematis. Menurut Widharyanto (2021), referensi gaya belajar tipe AK lebih senang memahami dan memperoleh informasi melalui aktivitas praktik yang melibatkan motorik fisik, olah tubuh, dan mengalami langsung dalam situasi kelas atau di luar kelas. Aktivitas seperti membuat benda poster atau iklan, mendemonstrasikan suatu gerakan, drama atau role playing, observasi lapangan, dan dilanjutkan dengan diskusi yang mengandalkan kemampuan pendengaran, merupakan aktivitas bahasa yang mereka minati. Sedangkan siswa dengan tipe belajar Visual-Kinestetik juga belum memenu-hi indikator koneksi matematis. Siswa dengan tipe ini memiliki kecende-rungan belajar mengamati gambar dan grafik pada tipe visual dan menyukai praktik.

\section{Kemampuan Koneksi Matematis Ditinjau dari Gaya Belajar Trimodal} (T)

Subjek penelitian yang dipilih untuk gaya belajar trimodal dengan tipe Audio-Read/Write-Kinestetic (ARK) adalah T-1 dan Visual-AuditoryKinestetic (VAK) adalah T-2

\section{Subjek T-1}

Subjek T-1 masih menemui kekeliruan dalam menyelesaikan soal nomor 1 dan 2. Sedangkan untuk nomor 3, Subjek T-1 mampu menjawab soal dengan benar. Berdasarkan hasil wawancara, Subjek T-1 menyatakan tidak tahu koneksi antar topik matematika dalam soal nomor 1 dan tidak bisa menemukan hubungan matematika dan kehidupan pada soal nomor 2. Akan tetapi, untuk soal nomor 3, Subjek T-1 mampu menemukan koneksi soal tersebut dengan disiplin ilmu lain yaitu fisika. 
DOI: https://doi.org/10.24127/ajpm.v10i4.4417

\section{Subjek T-2}

Subjek T-2 belum mampu menyelesaikan soal yang diberikan dengan benar. Berdasarkan hasil wawancara, diketahui Subjek T-2 tidak mengetahui adanya hubungan antar topik matematika pada soal tersebut dan disiplin ilmu lain. Namun subjek bisa menemukan koneksi soal nomor 2 dengan kehidupan sehari-hari.

Berdasarkan analisis tes dan wawancara diperoleh hasil bahwa siswa dengan gaya belajar tipe trimodal juga belum memenuhi seluruh indikator kemampuan koneksi matematis. Tipe belajar trimodal memiliki karakteristik gabungan dari masingmasing modalitas.

\section{Kemampuan Koneksi Matematis Ditinjau dari Gaya Belajar Quadmodal (Q)}

Subjek penelitian yang dipilih untuk gaya belajar dengan tiper VARK-1 adalah Q-1 dan VARK-2 adalah Q-2

\section{Subjek Q-1}

Subjek Q-1 mampu memahami soal namun tidak bisa menjawab hingga akhir penyelesaian dengan hasil yang benar. Subjek Q-1 menyebutkan dalam wawancara bahwa mengalami kesulitan untuk melanjutkan penyelesaiannya. Subjek Q-1 juga menjawab tidak tahu ketika ditanya koneksi matematis soal tersebut berdasarkan indikatornya.

\section{Subjek Q-2}

Subjek Q-2 mampu menuliskan apa yang diketahui dan ditanyakan soal namun mengalami kesulitan dalam menyelesaikan ketiga soal yang diberikan. Berdasarkan wawancara, subjek Q-2 mengetahui ada koneksi antar topik matematika pada soal nomor 1, namun tidak mampu menemukan koneksi matematika dengan kehidupan sehari-hari dan disiplin ilmu lain yang terdapat pada soal nomor 2 dan 3.

Hasil analisis Subjek Q-1 dan Q2 menunjukkan bahwa siswa dengan gaya belajar Visual, Auditory, Read/write dan Kinestetic secara umum mampu menjawab soal terkait menghubungkan antar matematika, yaitu mampu menyelesaikan permasalahan dengan menggunakan prosedur atau operasi tertentu dalam menjawab soal. Subjek dengan tipe gaya belajar ini memiliki kecenderungan mudah memahami informasi dengan memanfaatkan modalitas yang dimiliki. Jika subjek ini mampu memaksimalkan gaya belajarnya maka subjek mampu untuk belajar dengan berbagai versi.

Berdasarkan hasil analisis kemampuan koneksi matematis siswa berdasarkan gaya belajar, diperoleh tinggi rendahnya kemampuan koneksi matematis siswa tergantung pada gaya belajar yang dimiliki oleh siswa tersebut.

Siswa dengan gaya belajar unimodal (A, dan $\mathrm{R}$ ) adalah kelompok siswa yang secara umum mampu melakukan koneksi matematis dalam menyelesaikan soal yang diberikan. Sedangkan siswa dengan gaya belajar kinestetik hanya mampu melakukan koneksi matematika terhadap disiplin ilmu lain dalam menyelesaikan soal matematika. Hal ini sesuai dengan penelitian (Apipah \& Kartono, 2017; Indrahapsari et al., 2018) bahwa siswa dengan gaya belajar kinestetik memiliki kemampuan koneksi matematis sedang dan siswa dengan gaya belajar kinestetik kurang mampu mengaitkan pada aspek koneksi satu topik yang ditandai dengan penulisan langkah penyelesaian masalah kurang sistematis. 
Siswa dengan gaya belajar quadmodal (VARK) adalah kelompok siswa yang mampu menggunakan koneksi matematis dalam menyelesaikan soal matematika. Hal ini disebabkan karena setiap unsur gaya belajar dimiliki oleh kelompok siswa ini, sehingga jika kelompok ini memahami dan memaksimalkan gaya belajarnya, maka kemampuan koneksi matematiskan sangat tinggi dengan gaya belajar berbagai versi yang dimilikinya. Hal ini sesuai dengan pendapat (K et al., 2021) bahwa pada gaya belajar quadmodal (VARK) semua karakter gaya belajar berada pada satu orang sehingga perpaduan semua karakter gaya belajar tersebut secara bersama memberikan pengaruh.

Penelitian ini menggunakan gaya belajar VARK sebagai peninjau sehingga masih sulit menemukan referensi terkait VARK itu sendiri, khususnya kemampuan koneksi matematis ditinjau dari gaya belajar VARK. Namun di sisi lain, penggunaan gaya belajar VARK ini menjadikan penelitian ini bernilai lebih dari penelitian yang lain, karena dari beberapa penelitian terkait koneksi matematis berdasarkan gaya belajar, seperti (Apipah \& Kartono, 2017; Indrahapsari et al., 2018; Widyawati, 2016), belum menggunakan atau belum membahas terkait gaya belajar VARK,namun masih menggunakan gaya belajar VAK sehingga tidak adanya pengelompokan unimodal, bimodal, trimodal dan quadmodal dalam gaya belajar.

\section{KESIMPULAN DAN SARAN}

Berdasarkan hasil analisis dan pembahasan dari kemampuan koneksi matematis siswa IX SMPN 1 Tanggetada ditinjau dari gaya belajar dapat disimpulkan bahwa kemampuan koneksi matematis siswa kelas IX SMPN 1 Tanggetada berada pada kategori kurang. Adapun kemampuan koneksi matematis berdasarkan indikatornya yaitu pada indikator mengkoneksikan antar topik matematika berada pada kategori kurang, untuk indikator mengkoneksikan matematika dengan disiplin ilmu lain berada pada kategori kurang sekali, dan untuk indikator mengkoneksikan matematika dalam kehidupan sehari-hari berada pada kategori cukup. Sedangkan koneksi matematis ditinjau dari gaya belajar untuk semua tipe berada pada kategori kurang selain tipe $\mathrm{V}-\mathrm{A}-\mathrm{K}$ yang berada pada kategori cukup.

Saran dalam penelitian ini bagi peneliti selanjutnya adalah perlu penelitian lanjutan untuk meningkatkan kemampuan koneksi matematis siswa. Adapun saran bagi guru sebaiknya sering melatih siswa mengerjakan soal yang memuat indikator kemampuan koneksi matematis dan mempertimbangkan model pembelajaran berdasarkan gaya belajar siswa masing-masing.

\section{DAFTAR PUSTAKA}

Apipah, S., \& Kartono. (2017). Analisis Kemampuan Koneksi Matematis Berdasarkan Gaya Belajar Siswa pada Model Pembelajaran VAK dengan Self Assessment. Ujmer: Innes Journal of Mathematics Educatioan Research, 6(2), 148156.

https://journal.unnes.ac.id/sju/inde x.php/ujmer/article/view/20472

Dwiwandira, N. R., \& Tsurayya, A. (2021). Analisis Kemampuan Koneksi Matematis Siswa SMA Kelas XI dalam Menyelesaikan Soal Materi Pengaplikasian Kalkulus pada Turunan. Jurnal Cendekia: Jurnal Pendidikan Matematika, 5(3), 2560-2569. 
DOI: https://doi.org/10.24127/ajpm.v10i4.4417

https://doi.org/10.31004/cendekia. v5i3.898

Elisahaya, \& Imami, A. I. (2020). Analisis Kemampuan Koneksi Matematis Pada Materi Segiempat. Seminar Nasional Matematika Dan Pendidikan Matematika, 53-61. https://journal.unsika.ac.id/index. php/sesiomadika/article/view/229 2

Haidar, I., \& Jahring. (2020). The Effectiveness Of Methaporical Thinking Approach To Improve The Mathematical Representation Ability. In Daya Matematis: Jurnal Inovasi Pendidikan MatematikaJurnal Inovasi Pendidikan Matematika (Vol. 8, Issue 1). https://doi.org/10.26858/jds.v8i1. 13321

Hasratuddin. (2013). Membangun Karakter Melalui Pembelajaran Matematika. PARADIKMA Jurnal Pendidikan Matematika, 6(2), 130-141.

Indrahapsari, B., Sujatmiko, P., \& Chrisnawati, H. E. (2018). Analisis Kemampuan Koneksi Matematis pada Materi Trigonometri Ditinjau dari Gaya Belajar Siswa Kelas X SMKN 1 Surakarta Tahun Ajaran 20182019. Jurnal Pendidikan Matematika Dan Matematika (JPMM) Solusi, 2(6), 483-490.

Isnaeni, S., Ansori, A., Akbar, P., \& Bernard, M. (2019). Analisis Kemampuan Koneksi Matematis Siswa SMP Pada Materi Persamaan dan Pertidaksamaan Linear Satu Variabel. Jurnal On Education, 1(2), 309-316. https://doi.org/10.31004/joe.v1i2. 68

Jahring, J. (2020). Kemampuan Koneksi
Matematis Pada Model Pembelajaran Connecting, Organizing, Reflecting, Extending dan Numbered Head Together. Aksioma: Jurnal Program Studi Pendidikan Matematika, 9(1), 182-189.

https://doi.org/10.24127/ajpm.v9i 1.2667

Jahring, J., \& Chairuddin, C. (2019). Preferensi Modalitas Belajar Mahasiswa Angkatan 2016 Program Studi Pendidikan Matematika Universitas Sembilanbelas November Kolaka. Square: Journal of Mathematics and Mathematics Education, 1(1), 27-32.

https://doi.org/10.21580/square.v1 i1.4039

K, I., Jahring, \& Subawo, M. (2021). Analisis Kemampuan Komunikasi Matematis Siswa Ditinjau Dari Gaya Belajar. Square: Journal of Mathematics and Mathematics Education, 3(1), 56-65. https://doi.org/10.21580/square.20 21.3.1.7704

Manalu, A. C. S., Septiahani, A., Permaganti, B., Melisari, Jumiati, Y., \& Hidayat, W. (2020). Analisis Kemampuan Koneksi Matematis Siswa SMK pada Materi Fungsi Kelas XI. Jurnal Cendekia: Jurnal Pendidikan Matematika, 4(1), 254-260. https://doi.org/10.31004/cendekia. v4i1.198

Mandur, K., Sadra, W., \& Suparta, I. N. (2013). Kontribusi Kemampuan Koneksi, Kemampuan Representasi, dan Disposisi Matematis Terhadap Prestasi Belajar Matematika Siswa SMA Swasta Di Kabupaten Manggarai. Jurnal Pendidikan Dan Pembelajaran Matematika 
DOI: https://doi.org/10.24127/ajpm.v10i4.4417

Indonesia, 2(2), 36-45. https://doi.org/10.23887/jppm.v2i 2.885

Mashuri, S., Jahring, J., \& Nasruddin, N. (2020). Student Teams Achievement Divisions (STAD) Dengan Pendekatan Realistic Mathematics Education (RME) Terhadap Kemampuan Pemahaman Matematis. AKSIOMA: Jurnal Program Studi Pendidikan Matematika, 9(4), 909-916.

https://doi.org/10.24127/ajpm.v9i

4.2979

NCTM. (2000). Principles and Standars for School Mathematics. VA NCTM.

Puteri, J. W., \& Riwayati, S. (2017). Kemampuan Koneksi Matematis Siswa pada Model Pembelajaran Connected Mathematics Project (CMP). FIBONACCI: Jurnal Pendidikan Matematika Dan Matematika, 3(2), 161-168. https://doi.org/10.24853/fbc.3.2.1 61-168

Widyawati, S. (2016). Pengaruh Kemampuan Koneksi Matematis Siswa Terhadap Prestasi Belajar Matematika Ditnjau Dari Gaya Belajar Pada Materi Bangun Ruang Sisi Datar Siswa Kelas IX SMP Di Kota Metro. IQRA: Jurnal Kajian Ilmu Pendidikan, 1(1), 47-67. https://journal.iaimnumetrolampu ng.ac.id/index.php/ji/article/view/ 33 